Eur Neurol 2002;48:37-39

\section{Successful Systemic Thrombolysis for Carotid Stent Thrombosis}

Gerhard F. Hamann a , Martin Liebetrau a, Thomas Pfefferkorn a, Markus M. Heiss ${ }^{b}$

aDepartment of Neurology and bDepartment of Surgery, Ludwig Maximilian University, Klinikum Grosshadern,

Munich, Germany

Carotid artery stenting is an increasingly used treatment for carotid artery stenosis [1-3]. The complications include minor and major stroke and peri-interventional death [4]. Stent thrombosis is rarely reported to occur during the treatment of carotid stenosis, and there has been one report on the successful use of a glycoprotein IIb/ IIIa antagonist [5].

\section{Case Report}

A 76-year-old man was admitted with symptoms consistent with a right middle cerebral artery (MCA) infarction. He was on his way home from a surgical ward, where he had received a stent 4 days before. The stent had been placed in the right internal carotid artery (ICA) to treat a 70\% ICA stenosis which produced right-sided amaurosis fugax. The patient had had two previous endarterectomies on the same side. Immediately after stenting, which was confirmed to be successful by angioscopy, the patient received aspirin and intravenous heparin. His postoperative course was uneventful. It was planned to maintain the patient on $300 \mathrm{mg}$ aspirin daily, but on hospital discharge he had been given neither anticoagulation nor aspirin by mistake. The treatment regimen at that time did not include clopidogrel. The neurological examination showed hemiparesis, hemineglect and hemianopia on the left side (NIHSS 16). The color-coded duplex sonography showed a thrombotic occlusion of the stented right ICA (fig. 1a) and an occlusion of the right MCA. Cranial computed tomography only revealed on old, right-sided posterior watershed infarct (fig. 2). The acute thrombosis of the stent was thought to be the source of an embolism of the right MCA. Since the patient fulfilled the criteria for intravenous thrombolysis, we started intravenous thrombolysis $2 \mathrm{~h}$ after the initial symptoms, using $70 \mathrm{mg}$ rt-PA. Besides the thrombolysis, the patient immediately received intravenous heparin. The patient started to improve $30 \mathrm{~min}$ after initiation of thrombolysis. An ultrasound examination $1 \mathrm{~h}$ after the thrombolysis revealed an open stent (see fig. 1b) and restored normal right MCA blood flow velocity. The patient was discharged 5 days later. He still had a slight motor deficit (NIHSS 2), but a score of 1 on the Rankin scale and a Barthel index of 100 .

\section{Discussion}

While stenting is widely used in cardiology, only limited experience has been gathered on its use in carotid artery disease $[1,2]$. About 5,210 procedures have been reported worldwide (technical success rate $98.4 \%$; transient ischemic attacks $2.82 \%$, minor strokes $2.72 \%$, major strokes, $1.49 \%$; deaths $0.86 \%$ ) [1]. Various clinical trials are being planned or are in progress to establish the indications for carotid artery stenting (CREST, SPACE, CASET) [6]. Recently, the Carotid and Vertebral Artery Transluminal Angioplasty Study (CAVATAS) demonstrated similar 3-year results for endovascular treatment and carotid endarterectomy for major risks and effectiveness, and avoidance of minor complications [7]. Stent thrombosis is a well-known problem in cardiology [8]. A thrombosis rate of 3.5\% was reported as a first result [8]. Aggressive antiplatelet therapy, including the combined use of ticlopidin or clopidogrel and aspirin, reduces the rate of stent thrombosis to approximately $1 \%$ [8]. Platelet activation and aggregation may play a relevant role in the treatment of thrombotic occlusion of stented vessel segments [9]. Abciximab has been proposed in carotid stenting to prevent rethrombosis [9]. The treatment of early intracoronary stent thrombosis includes balloon angioplasty and intracoronary thrombolysis. Systemic thrombolysis has so far been attempted as a second therapeutic alternative [10]. We performed an intravenous rt-PA thrombolysis similar to the known NINDS protocol to reperfuse the MCA. In contrast to this protocol, heparin was given early because we hoped it would prevent another thrombosis, and indeed both the MCA and the thrombosed stent were recanalized. Thus, thrombolysis was able to dissolve a large thrombus in the stent and an embolus in the MCA. After the intervention, we discovered a recent case report about the intravenous administration of a glycoprotein IIb/IIIa receptor antagonist to recanalize acute stent thrombosis [7]. To the best of our knowledge, this is the first report of the use of intravenous thrombolysis to successfully recanalize a carotid stent thrombosis with concomitant embolic MCA occlusion. Obviously, this single case can only help to illuminate the available treatment options rather than provide general therapeutic recommendations.

\section{Acknowledgments}

Gerhard F. Hamann is a recipient of a research grant from Böhringer Ingelheim Inc., Biberach an der Riss, Germany, in recognition of his experimental work on the development of intracranial bleeding following acute ischemic stroke.

The authors want to express their warmest thanks to Mrs. J. Benson for editing the manuscript.

\section{KARGER}

Fax + 41613061234

E-Mail karger@karger.ch

www. karger.com

\section{(C) 2002 S. Karger AG, Basel}

Accessible online at

www. karger.com/journals/ene 

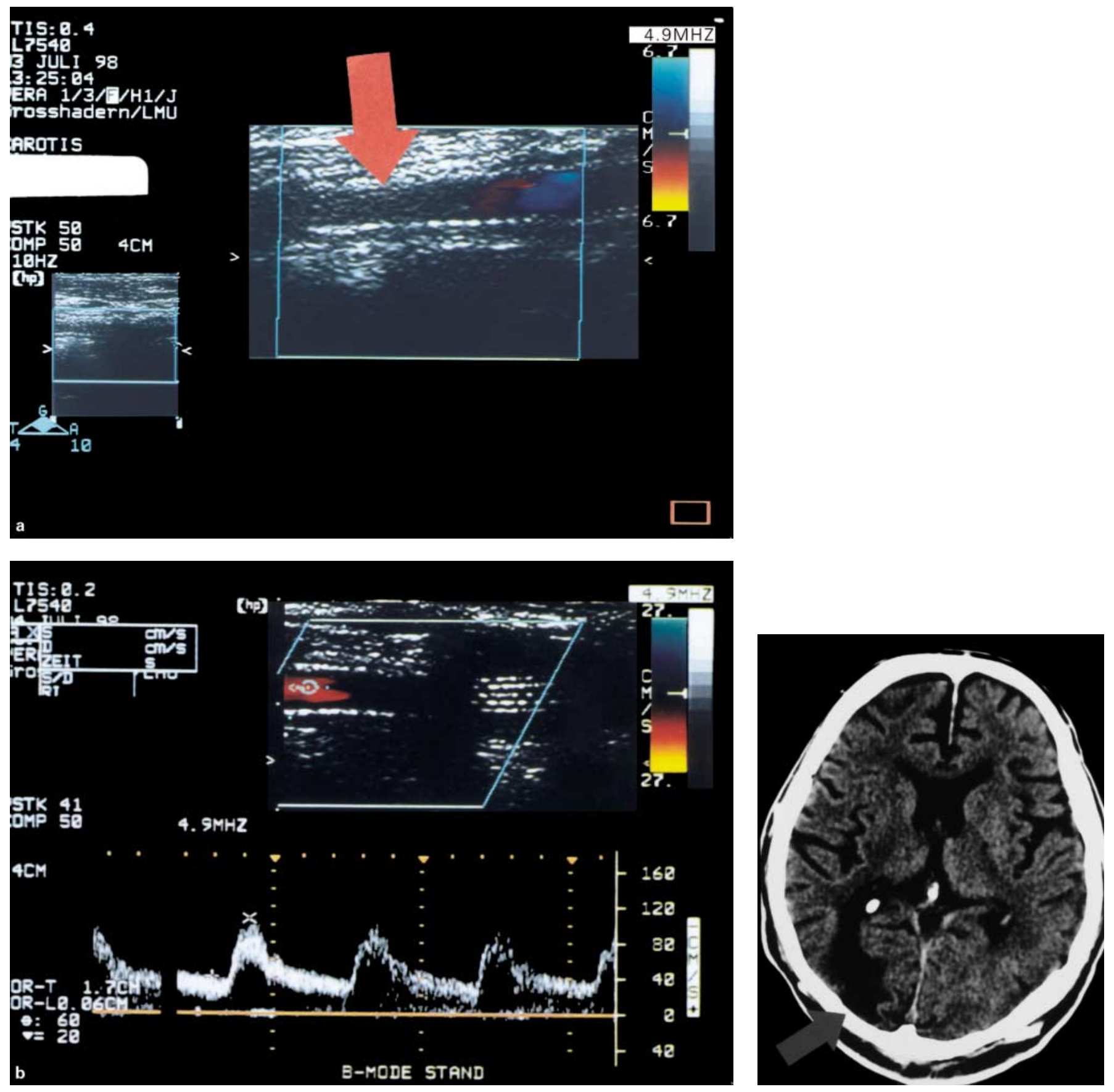

Fig. 1. a Color-coded duplex sonography of the right ICA demonstrating the thrombotic occlusion of this vessel (arrow) before treatment. b Color-coded duplex sonography of the right ICA after systemic thrombolysis showing the restored blood flow and the reopened vessel.

Fig. 2. Cranial computed tomography $1 \mathrm{~h}$ after the onset of initial symptoms of an acute MCA right-sided stroke. No early signs of infarction were detected, but an old watershed infarction (arrow) is visible between the territory of the MCA and the posterior cerebral artery on the right side. Courtesy of Prof. Brückmann, Head Institute of Neuroradiology, Ludwig Maximilian University, Munich, Germany. 


\section{References}

1 Wholey MH, Wholey M, Mathias K, Roubin GS, Diethrich EB, Henry M, Bailey S, Bergeron P, Dorros G, Eles G, Gaines P, Gomez CR, Gray B, Guimaraens J, Higashida R, Ho DS, Katzen B, Kambara A, Kumar V, Laborde JC, Leon M, Lim M, Londero H, Mesa J, Musacchio A, Myla S, Ramee S, Rodriguez A, Rosenfield K, Sakai N, Shawl F, Sievert H, Teitelbaum G, Theron JG, Vaclav P, Vozzi C, Yadav JS, Yoshimura SI: Global experience in cervical carotid artery stent placement. Cathet Cardiovasc Interv 2000;50:160-167.

2 Roubin GS, New G, Iyer SS, Vitek JJ, Al-Mubarak N, Liu MW, Yadav J, Gomez C, Kuntz RE: Immediate and late clinical outcomes of carotid artery stenting in patients with symptomatic and asymptomatic carotid artery stenosis: A 5-year prospective analysis. Circulation 2001;103:532537.

3 Veith FJ, Amor M, Ohki T, Beebe HG, Bell PR, Bolia A, Bergeron P, Connors JJ 3rd, Diethrich EB, Ferguson RD, Henry M, Hobson RW 2nd, Hopkins LN, Katzen BT, Matthias K, Roubin GS, Theron J, Wholey MH, Yadav SS: Current status of carotid bifurcation angioplasty and stenting based on a consensus of opinion leaders. J Vasc Surg 2001;33:S111-S1 16.

4 Mathur A, Roubin GS, Iyer SS, Piamsonboon C, Liu MW, Gomez CR, Yadav JS, Chastain HD, Fox LM, Dean LS, Vitek JJ: Predictors of stroke complicating carotid artery stenting. Circulation 1998;97:1239-1245.

5 Tong FC, Cloft HJ, Joseph GJ, Samuels OB, Dion JE: Abciximab rescue in acute carotid stent thrombosis. Am J Neuroradiol 2000;21:1750-1752.

6 Hobson RW 2nd: Carotid angioplasty-stent: Clinical experience and role for clinical trials. J Vasc Surg 2001;33:S117-S123.

7 CAVATAS Investigators: Endovascular versus surgical treatment in patients with carotid stenosis in the Carotid and Vertebral Artery Transluminal Angioplasty Study (CAVATAS): A randomised trial. Lancet 2001;357: 1729-1737.

8 Baim DS, Carrozza JP Jr: Stent thrombosis. Closing in on the best preventive treatment. Circulation 1997;95:1098-1100.

9 Schneidermann J, Morag B, Gerniak A, Rimon U, Varon D, Seligsohn U, Shotan A, Adar R: Abciximab in carotid stenting for postsurgical carotid restenosis: Intermediate results. J Endovasc Ther 2000;7:263-272.

10 Fruhwald FM, Luha O, Eber B, Schuhmacher M, Zweiker R, Klein W: Systemic thrombolysis for early intracoronary stent thrombosis. Lancet 1995;346:119-120.

Prof. Gerhard F. Hamann, MD, Department of Neurology,

Ludwig Maximilian University, Klinikum Grosshadern,

Marchioninistrasse 15, D-81377 Munich (Germany)

Tel. +49 897095 3670, Fax +49 8970953677 ,

E-Mail hamann@brain.nefo.med.uni-muenchen.de 